\title{
O PRINCÍPIO DAS COISAS
}

Michelle Aranda Facchin ${ }^{1}$

O cair da tarde veio e com ele a sensação de Eliberto. Sua sorte mudou novamente. Após uma série de infortúnios, descontentamentos e frustrações, cuja razão já tentara saber, chegou o momento de usufruir todo o prazer das conquistas sofridas. Qual seria a razão para tal mudança de sorte? Como isso sucedeu? Sentiu um estranhamento naquele final de tarde em que saíra de uma longa jornada de trabalho no museu da cidade de Paranambá. Percebeu um aspecto diferente nas coisas ao seu redor: o movimento dos carros, a simpatia das árvores que resistiam ao vento forte, cortejando o seu caminhar.

Atravessou a avenida e mais uma vez sentiu que a sorte era sua companheira: lá estava o semáforo à espera de sua travessia, assim como o fizera muitas vezes sua mãe nas manhãs em que se atrasava para o jantar. Sentiu um aspecto de renovação nas coisas, mas precisava ao menos de uma confirmação, algo realmente concreto, vindo do mundo das pessoas normais, caracteristica que nunca foi sua. Ser normal, eis algo que nunca será, embora mesmo já houvesse tentado tantas vezes. Não podia... simplesmente não era de sua natureza ser comum.

Paulatinamente já se dera conta da impossibilidade de ser como outrem. Devia sim aceitar sua realidade para ao menos ser feliz. De

\footnotetext{
${ }^{1}$ Mestranda da Unesp.
} 
repente despertou; algo não o deixara continuar em suas divagações. Havia, naquele momento, o tilintar predominante de um só pensamento: o que lhe proporcionara tal mudança?

Era no mínimo indagadora a origem de tal transformação, principalmente após tamanha força despendida durante seus 30 anos de vida para encontrar tais respostas. Muitas das vezes em que se viu pensando nisso, algo o impediu de concluir seus pensamentos. Seria desventura estar mudado? Pensou em aceitar tal desconcerto como um simples resultado da vida diária de todos os seres pensantes, contudo isso não o satisfez com o mesmo poder que os jogos de infância têm sobre uma criança. Precisava de muito mais para confortar sua alma desconcertada, talvez até precisasse escapar um pouco do cotidiano, alimento eterno de sua existência atroz, corroída de desencantos e entremeios de vida e morte. Caminho de aventuras e ao mesmo tempo pessimismo.

Agora era a hora da verdade tão almejada. Foram várias as tentativas anteriores para chegar à resolutória explicação. Certa vez, tentou ir a uma benzedeira das boas para ver se encontrava a origem dos acontecimentos por ora desconcertantes. A velha Manô, como a chamavam, era muito entendida desses assuntos de mau agouro. $\mathrm{Na}$ antiga casa em que vivia, costumava atender uma meia dúzia de pessoas por dia em troca de donativos. Quando Eliberto entrou na sala, o cheiro de vela acesa, misturado à essência de almíscar, deu-lhe a sensação de quietude.

Alguns minutos após, veio a senhora Manô com seus trajes escuros e pesados como os de uma viúva entristecida, a expressão da face inerte diante da presença do outro e o galho de arruda entre os dedos da mão direita. Vinha como se fosse curá-lo de uma doença. Sussurrou uma prece com as mãos no alto de sua testa e o mandou embora em paz: "Que Deus lhe acompanhe".

Até mesmo a tentativa de perguntar algo fora desfeita pela expressão rápida da situação. Ninguém a questionava. Porém naquele momento Eliberto pôs-se a duvidar, mas sem dizê-lo, é claro, pois 
ficaria muito deselegante discordar de uma senhora tão respeitável. Foi assim que acabou desistindo de buscar o poder no além-vida.

Ainda que sucedeu uma tentativa de teor mais científico: consultar uma psicóloga. Manuela, velha na profissão, mais ouvia do que falava e nada acrescentava com suas indagações desgastadas. Pra que tentar ser o que não tem jeito. Simplesmente não tinha modo de transformá-lo assim em outra pessoa. Seria uma tonteria continuar pagando sessões tão pesadas. E assim decidiu abandonar também esse recurso, assim como o fizera com o curso na faculdade de Economia. Eram cálculos exatos demais para sua mente incomum. Eram demasiadas mentiras que tiveram de ser deglutidas por aquela alma insólita.

Tudo estava ruim, tudo o fizera mal e nada podia acalmá-lo de sua insanidade momentânea. Algo ainda o perturbava naquele momento de entardecer; a sensação de que a única resposta estaria em conformar-se com a única arma que talvez lhe fora dada: aceitar os fatos sem sequer questionar sua existência. Como obter respostas de um universo intangível como o dele? Até aquele momento nunca tivera explicação para os acontecimentos dessa natureza. A mudança acontecera, mas isso não o preocupava, queria mesmo é descobrir a causa da transformação, isso sim lhe importava saber. Para que lhe importaria entender o resultado, queria mesmo é a verdade gestatória de suas incertezas.

Magicamente algo se transformou em sua vida e o fez mudar por dentro, algo que ninguém podia reconhecer, apenas ele mesmo, sujeito solitário e fechado em si mesmo. Sua maior frustração resumia-se em pulsar os pensamentos dentro de sua cabeça para tentar saber a origem do que lhe sucedera, mas também não haveria de saber nunca porque os elementos de seu mundo anormal eram tantas vezes tão irreais a ponto de não lhe possibilitarem agir sobre si mesmo.

Bom mesmo é saber que a aceitação das situações que misteriosamente se colocam na vida de todos é um tanto forçada. Talvez no final daquela tarde ou no surgir do outro dia, ele viesse a descobrir 
que tudo fora apenas um momento de encantamento e, afinal, viesse a aceitar que tudo voltara ao normal dentro de si, se é que existe um normal real das coisas que carregamos dentro de nós. 